\title{
The occurrence of Aedes (Stegomyia) aegypti (Linnaeus) and Aedes (Stegomyia) albopictus (Skuse) in a rural area in Northern Paraná, Brazil and the associated Culicidae fauna ${ }^{1}$
}

\author{
José Lopes ${ }^{2}$
}

\begin{abstract}
To verify the possible occurrence of Aedes aegypti (Linnaeus, 1761) and Aedes albopictus (Skuse, 1894) in a rural area in Northern Paraná, Brazil, a water tank was installed on a farm, to work as an artificial breeding site. Collections were carried out every 15 days, during a period of 2 years. 12,876 Culicidae larvae, belonging to 10 different species, including Aedes aegypti and Aedes albopictus, were collected, indicating their occurrence.

KEY WORDS. Culicidae, larvae, artificial container breeding, Aedes aegypti, Aedes albopictus
\end{abstract}

Aedes (Stegomyia) aegypti (Linnaeus, 1762) and Aedes (Stegomyia) albopictus (Skuse, 1894) are the two main dengue virus transmitting species found in urban areas. In some Brazilian regions such disease has reached epidemic levels, and types I, II and III were detected.

Aedes aegypti is an urban, domicile mosquito, responsible for the occurrence of the urban yellow fever in Brazil in the early $20^{\text {th }}$ Century. Although it was eradicated in the ' 50 s, the re-incidence of this species took place in the '70s. In the beginning of the following decade, the first dengue epidemics broke out in Boa Vista, State of Roraima, Brazil. In the region of Londrina, State of Paraná, the presence of the vector was detected in 1985 (LOPES et al. 1993).

Aedes albopictus, a second species with epidemiological importance, was identified in Brazil for the first time in 1986 (FORATTINI 1986), and collected in the urban area of Londrina in the beginning of 1993, by Fundação Nacional da Saúde (The National Health Foundation), through systematic collections carried out throughout the urban perimeter. Such species, besides colonizing containers in the urban area, also colonizes natural and artificial breeding site in rural areas (GOMES et al. 1992).

LOPES (1997), in an extensive study carried out from 1988 to 1989 , in the rural area of Londrina, did not register the presence of either species. The present research aims at verifying the occurrence of Aedes aegypti and Aedes albopictus in that same rural area and their association with native species.

1) Research supported by Coordenadoria de Pesquisa e Pós-Graduação, Universidade Estadual de Londrina.

2) Departamento de Biologia Animal e Vegetal, Universidade Estadual de Londrina. Caixa Postal 6001, 86051-970 Londrina, Paraná, Brasil. E-mail: jea@uel.br 


\section{MATERIALS AND METHODS}

The selected site for this study is a typical coffee plantation farm, located approximately $2 \mathrm{Km}$ far from the urban area, with a small grazing area, some domestic animals, a few farm buildings, and the main house. Around the main house there were several containers with water which were used as larvae breeding site by Culicidae.

For two years, a breeding site made of a round 500 liter amianthus water tank with 200 liters of well water, was kept on the farm, being submitted to rain, evaporation, and decomposition of leaves an other vegetal fragments. The tank was placed near a tree, under its shade.

The experiment was carried out from February 1994 to December 1995, with fortnight collections. With the help of a small net, an attempt was made to collected all third and fourth stage larvae and pupae. Culicidae identification was made by the $4^{\text {th }}$ instar larvae and by the adults obtained in the laboratory. The material collected is now packed in the Laboratory of Entomology at the Department of Animal and Vegetal Biology, Londrina State University.

\section{RESULTS AND DISCUSSION}

12,876 Culicidae larvae were collected and analyzed ( $30.04 \%$ belonged to the Aedes aegypti species, and $2.27 \%$ belonged to the Aedes albopictus species). Table I shows all the species collected with their respective values. Results showed that the Aedes aegypti had already started to disperse in the rural area, becoming the second most frequently found species. An indication of Aedes albopictus occurrence was also registered. LOPES (1997), in 1988 and 1989, carried out an extensive research in the region, covering an extension of $11 \mathrm{~km}$, and studying all kinds of containers; however, he did not find any evidence of the species in the area.

Table I. Amount of larva from each collected species procreated in a water recipient located in a rural area in Southern Brazil, during the years of 1994 and 1995, and their respective averages per collection $(n=50)$.

\begin{tabular}{lcc}
\hline \multicolumn{1}{c}{ Species } & Quantity & Average \\
\hline Culex quinquefasciatus & 5,876 & 117.5 \\
Aedes aegypti & 4,641 & 92.8 \\
Aedes fluviatilis & 1,341 & 26.8 \\
Culex coronator & 354 & 7.1 \\
Aedes albopictus & 292 & 5.8 \\
Aedes terrens & 163 & 3.3 \\
Culex eduardoi & 146 & 2.9 \\
Toxorhynchites sp. & 32 & 0.6 \\
Anopheles argyritarsis & 16 & 0.3 \\
Culex saltanensis & 15 & 0.3 \\
\hline Total & 12,876 & \\
\hline
\end{tabular}

According to the records of the National Health Foundation, Londrina, the occurrence of Aedes albopictus was registered for the first time in March, 1993, at Jardim Adriana, in the urban area of Londrina. A year later, that same species was 
detected in the rural area, approximately $15 \mathrm{Km}$ away from the initial focus. GOMES et al. (1992) collected the species in a hole on a tree on a small farm $4 \mathrm{Km}$ away from the urban area of the City of São Paulo, and in 1987 it was detected in city's urban area (SOUBIHE et al. 1992).

Figures 1 and 2 show the population variation of the most frequently collected species in 1994 and 1995, respectively. As the figures show, Aedes aegypti succeeded Culex (Culex) quinquefasciatus (Say, 1823) and, in two years, when Aedes aegypti reached its higher population density, Culex quinquefasciatus and Aedes (Ochlerotatus) fluviatilis (Lutz, 1904) almost disappeared. Aedes aegypti was the most competitive species, being able to dislocate the native species. During the competition process, Aedes fluviatilis seems to had suffered the most with the introduction of Aedes aegypti in the rural area.
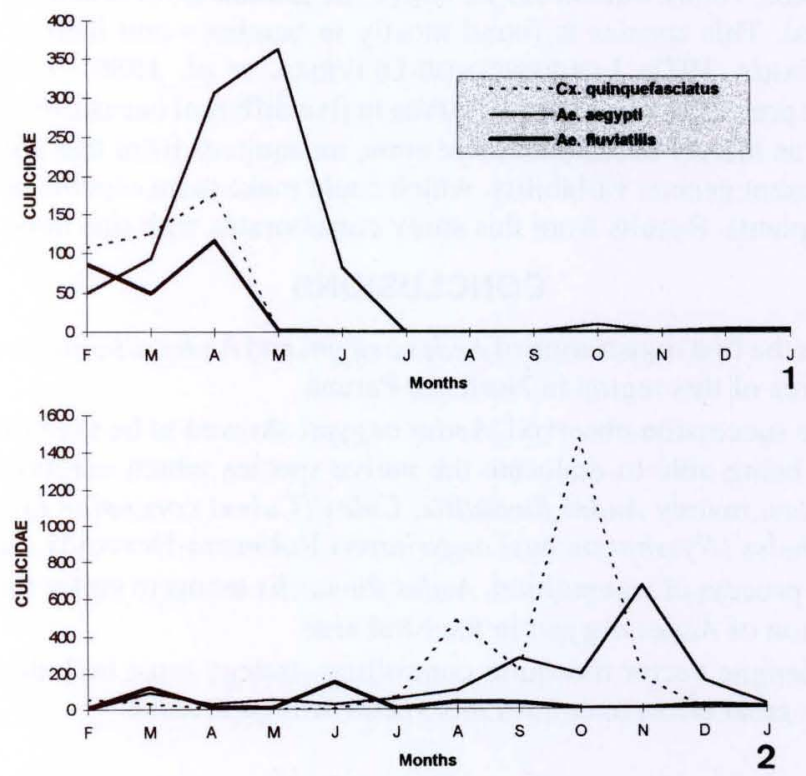

Figs 1-2. Population variation of larva of the most frequently found species of Culicidae collected in the water recipient, during the years of (1) 1994 and (2) 1995, in a rural area in Southern Brazil.

Aedes albopictus was less frequent but abundant. Although this was the first registration of this species in a rural area in the North of the State of Paraná, it has been characterized as the beginning of the dispersion process, which was limited to the outskirts of the city. The largest dispersion of Aedes aegypti is justified by its largest abundance in the urban area and by its re-introduction in the area of Londrina, eight years before Aedes albopictus. During the first year (Fig.1) of this research project, the colonization of the container was observed from February to June, and from then on, the larval population of Culicidae fell to around zero. In the first year, 
the large colonization took place in autumn, whereas in the second year (Fig. 2) a large abundance was observed during the spring. During winter and summer extreme temperatures, Culex quinquefasciatus, Aedes aegypti and Aedes fluviatilis were scarce.

This totally different form of fluctuation observed in the two years of study (Fig. 1 and 2) may have been more influenced by the water's chemical factors than by the environmental temperature itself. The water may suffer transformations due to substances released by the larvae as well as by the microbial action upon the organic material. The affirmation that such processes of population regulation truly influence population variation were made by KRAMER \& MULLA (1979), BENZEN \& APPERSON (1988), and others.

As for the other species collected, the presence of the Aedes(Protomacleaya) terrens (Walker, 1856), known for its above the ground level breeding frequency, was registered. This species is found mostly in bamboos and hallow tree trunks (NEVES \& FARIA 1971; LOURENCO-DE-OliVEIRA et al. 1986). LOPES (1996), registered the presence of this species larvae in five different occasions. This finding was not seen as merely occasional since some mosquitoes from that area's population could present genetic variability, which could make them capable of colonizing artificial recipients. Results from this study corroborates with this hypothesis.

\section{CONCLUSIONS}

This is the first registration of Aedes aegypti and Aedes albopictus occurrence in the rural area of this region in Northern Paraná.

By the succession observed, Aedes aegypti showed to be the most competitive species, being able to dislocate the native species which colonized artificial breeding places, mainly Aedes fluviatilis, Culex (Culex) coronator Dyar \& Knab, 1906 e Anopheles (Nysshorynchus) argyritarsis Robineau-Desvoidy, 1827.

In the process of competition, Aedes fluviatilis seems to suffer the most with the introduction of Aedes aegypti in the rural area.

Any dengue vector mosquito controlling strategy must include rural areas, otherwise the great effort to control this vector will be at stake.

ACKNOWLEDGEMENT. We would like to thank Dr. Maria Anice Mureb Sallum, from Faculdade de Saúde Pública, USP, for confirming the identification of the Culicidae species.

\section{REFERENCES}

Benzon, G.L. \& C.S. ApPerson. 1988. Reexamination of chemically mediated oviposition behaior in Aedes aegypti (L.) (Diptera: Culicidae). Jour. Med. Entomol. 25 (3): 158-164.

Forattinı, O.P. 1986. Identificação de Aedes (Stegomyia) albopictus (Skuse) no Brasil. Rev. Saúde Públ., São Paulo, 20 (3): 244-245.

Gomes, A. DE C.; O.P. Forattini; I. Kakitani; G.R.A.M. Marques; C.C. DE A. Marques; D. Marucci \& M. BRITo. 1992. Microhabitats de Aedes albopictus (Skuse) na Região do Vale do Paraíba, Estado de São Paulo, Brasil. Rev. Saúde Públ., São Paulo, 26 (2): 108-118.

Kramer, W. L. \& M.S. Mulla. 1979. Oviposition attractants and repellents of mosquitoeses to organic infusions. Environ. Entomol. 8 (6): 1111-1117. 
LOPES, J. 1996. Ecologia de mosquitoess (Diptera: Culicidae) em criadouros naturais naturais e artificiais de área rural, no Norte do Paraná, Brasil. IV. Espécies silvestres reproduzindo-se em recipientes. Arq. Biol. Tecnol., Curitiba, 39 (3): 671-676.

1997. Ecologia de mosquitoess (Diptera: Culicidae) que procriam em criadouros naturais e artificiais em área rural do Norte do Paraná, Brasil. VI. Coleta de larva no Peridomicílio. Revta bras. Zool. 14 (3): 571-578.

Lopes, J.; M.A.N. Da Silva; A.M. Borsato; V.D.R. DE Oliveira \& F.J. DE A. Oliveira. 1993. Aedes (Stegomyia) aegypti L. e a culicideofauna associada em área urbana da região sul, Brasil. Rev. Saúde Públ., São Paulo, 27 (5): 326-333.

Lourenço-de-Oliveira, R.; R. Heyden \& T.F. DA Silva. 1986. Alguns aspectos da ecologia de mosquitoess (Diptera, Culicidae) de uma área de planície (Granjas Calábria), em Jacarepaguá, Rio de Janeiro. V Criadouros. Mem. Inst. Oswaldo Cruz 81 (3): 265-271.

Neves, D.P. \& A.C. DE FARIA. 1971. Biologia de Aedes (Finlaya) terrens (Walker) em condições de campo e laboratório (Diptera, Culicidae). Rev. Brasil. Biol. 37 (4): 803-806.

Soubihe, V.; J.M.S. Barata; D. Natal \& A.I.P. DA Costa. 1992. Presença de Aedes (Stegomyia) albopictus (Skuse) na cidade de São Paulo - SP., Brasil. Rev. Saúde Públ., São Paulo, 26 (1):57.

Received in 10.VIII.2001; accepted in 09.X.2002. 